\title{
Discriminating Language Rights and Politics in the Post-Yugoslav States
}

\author{
Vanessa Pupavac, School of Politics and International Relations, University of \\ Nottingham NG7 2RD, vanessa.pupavac@nottingham.ac.uk
}

Published in the journal Patterns of Prejudice, Vol. 40, No. 2, 2006, pp. 112-128.

\begin{abstract}
Pupavac examines the rise of linguistic human rights advocacy and its approach in a case study of language politics in the post-Yugolav states. A core concern of contemporary linguistic rights advocacy has been to tackle ethnically based discrimination and promote ethnic diversity. It does not only seek to prevent states from discriminating against those who speak minority languages. It expects states to take positive steps to preserve their diversity of languages. However strategies affirming distinct linguistic identities may become complicit in perpetuating ethnic discrimination and ethnic divisions, as is evident in the language politics of the post-Yugoslav states.
\end{abstract}

\section{Linguistic human rights advocacy and its discontents}

There has been a remarkable expansion of international human rights advocacy over the last decade. This expansion has inspired a new movement for linguistic human rights. Not only has more attention been paid to existing language rights in existing international documents, but important new documents and provisions have been codified such as the UN Declaration on the Rights of Persons Belonging to National or Ethnic, Religious and Linguistic Minorities 1992 or the European Charter for Regional or Minority Languages 1992. Linguistic human rights advocacy, as the titles of these documents indicate, has become linked to what is known as the third generation of rights, namely cultural or identity rights. Linguistic human rights advocacy seeks to prevent language loss and foster minority languages to improve interethnic relations and the status of minorities. However, this paper identifies certain problems with linguistic rights as identity rights as a means of improving interethnic relations and the status of minorities.

The linguistic human rights literature has predominately been written from an advocacy perspective. Consequently the literature has tended to assume that rights' recognition must advance groups' rights and well-being. However, if we understand the development of human rights, as law in general, has had historically both progressive and repressive strands, then we cannot assume that the codification of particular rights necessarily promotes social justice and political freedoms. But in making precisely this assumption, most human rights literature has revolved around rights protection, around the codification and implementation of rights. Consequently much human rights literature has been rather impatient with discussing the nature of rights. Thus Susan Mendus speaks of how 'We should begin, not with a theoretical anxiety about the nature and origin of rights, but rather with a political question about what protection rights can afford us'.

Nevertheless a glance at the history of minority rights, to which linguistic rights have become linked, demonstrates abhorrent past uses under the Nazis and Apartheid, undermining social justice and political freedoms. As the philosopher Hannah Arendt 
reminds us, 'minority treaties did not necessarily offer protection but could also serve as an instrument to single out certain groups for eventual expulsion', that is, facilitate their statelessness. ${ }^{2}$ These abhorrent uses should at least serve to make us pause and reflect upon the nature of the rights being advocated and whether they do advance justice and freedom. Of relevance to linguistic human rights thinking, there has been a tendency to assume that the 1990s' codification of international human rights expands people's rights and that the three successive generations of human rights are compatible with each other. However, tensions exist between language rights as freedom of communication and language rights as identity recognition. Language rights as identity recognition can exacerbate ethnic divisions rather than overcome them. At the same time the codification of rights as identity recognition can represent a diminished model of justice: bureaucratic administration of justice rather than substantive justice.

The article will explore the problems of discriminating language rights through an analysis of language politics in the post-Yugoslav states. Language has been an important aspect of nationalist politics in the region. Indeed disputes over language rights prefigured the ethnic divisions of the war. Yet ironically SFR Yugoslavia had one of the most extensive provisions for language rights in the world. Indeed the country had contributed to the drafting of international linguistic rights documents prior to its break-up. Nevertheless language became a site of political contestation in which disputes were not confined to the position of Slovenian, Macedonian, Albanian, Hungarian or other languages versus the dominant language formerly known as Serbo-Croatian, but involved disputes over the codification of the latter as a single language. The break-up of SFR Yugoslavia has involved the break-up of SerboCroatian as an official language and the designation of distinct Bosnian, Croatian, Montenegrin and Serbian official languages, commonly referred to as BCS among international interpreters, whose usage I will follow here.

The successor states have signed up to key international human rights documents. The Constitution of Bosnia and Herzegovina has incorporated international human rights conventions as Bosnian law including the European Charter for Regional or Minority Languages 1992 and the Framework Convention for the Protection of National Minorities $1994 .{ }^{3}$ Its constitution also contains a non-discrimination clause, which includes the ground of language. ${ }^{4}$ Ironically, however, linguistic human rights discourse, despite its conscious goal of preventing discrimination, has actually helped legitimise ethnic divisions in the post-Yugoslav states. Importantly nationalists in the region have been invoking linguistic rights to assert difference, support negative stereotyping and demarcate ethnic minorities from mainstream society. BCS language politics illustrates how the designation of linguistic minority status can be experienced as exclusionary and being deprived of full citizenship rights. Equally the assertion of distinct language claims can be an obstacle to ethnic coexistence. In other words, more can mean less, in which minority rights can be used to deny rights and deter reconciliation. The case is of relevance not only to the needs of ethnic minorities and refugees in the new expanded Europe but to linguistic policies in other post-conflict areas such as Northern Ireland.

I begin by outlining how the evolving linguistic human rights framework conceptualises linguistic rights as encompassing positive identity recognition, not simply negative civil freedoms. I then highlight the influence of identity politics and 
the importance of identity recognition in the contemporary understanding of justice. Finally I examine the definition of a language in linguistic rights advocacy and its application to BCS language politics.

\section{Recognising linguistic identity}

Language rights have been given new prominence under international law since the end of the Cold War. Linguistic human rights thinking has basically followed the prevailing patterns in the human rights sector and its interest in group, cultural or identity-based rights. Greater emphasis has been put on collective rights in linguistic human rights advocacy. ${ }^{5}$ Individual linguistic rights evidently mean little if one cannot exercise them with other people, for language is fundamentally about communication. However, linguistic human rights advocacy over the last two decades has not been concentrated on collective rights to freedom of expression and assembly, but has been 'committed to the struggle for the promotion, preservation and protection of language minority communities' ${ }^{6}$, that is, maintaining language diversity and securing the right to communicate in a specific language. ${ }^{7}$ The maintenance of specific languages is treated as a fundamental rather than just an enrichment-orientated right. ${ }^{8}$ Thus an advocate speaks of how, 'The continued survival of languages must be seen as a fundamental human rights concern that cannot be abrogated without a compelling governmental interest'.

Earlier international documents such as the UN Charter 1945 or the Universal Declaration of Human Rights 1948 basically provide non-discrimination and freedom of expression clauses. Accordingly the International Covenant on Civil and Political Rights 1966 provides that persons belonging to ethnic, religious or linguistic minorities 'shall not be denied the right, in community with other members of their group $[. .$.$] to use their own language'. { }^{10}$ The actions expected of states are concerned with individuals' access to general rights, rather than with protecting specific languages. In contrast, the evolving international human rights framework now requires states actively to maintain linguistic identities, not simply refrain from discriminating on the basis of language. The UN Declaration on the Rights of Persons Belonging to National or Ethnic, Religious and Linguistic Minorities 1992, for example, requires states to 'protect the existence and the national or ethnic, cultural, religious and linguistic identity of minorities within their respective territories, and shall encourage conditions for the promotion of that identity'. ${ }^{11}$ To realise this objective, the 1992 Declaration requires states to 'take measures to create favourable conditions to enable persons belonging to minorities to express their characteristics and to develop their culture, language, religion, traditions and customs'. ${ }^{12}$ Likewise the Council of Europe's European Charter for Regional or Minority Languages 1992 requires positive affirmation of linguistic identity in their public and private usage.

Consider, for example, how the 1966 Covenant refers to 'free assistance of an interpreter if he cannot understand or speak the language used in court ${ }^{13}$. In other words, individuals are entitled to an interpreter in court to help their comprehension and ability to represent their case, not to affirm their linguistic identity. However, the 1992 European Charter precisely requires courts to recognise linguistic identity, as its Committee of Experts reiterates in its report to Croatia, which I quote at length: 
It should be underlined that this provision [Article 9], whereby the Parties undertake to guarantee the accused the right to use his/her regional or minority language, goes beyond the right of the accused, as laid down in Article 6 paragraph 3.e of the European Convention on Human Rights, to have the free assistance of an interpreter if he cannot understand or speak the language used in court. This measure goes further in the sense that speakers of a regional or minority language may use that language before a court of law, even if they are capable of communicating in the official language, thereby creating or enlarging the space for the use of these languages in the public sphere. ${ }^{14}$

In short, fundamental linguistic human rights are deemed in today's human rights approach to encompass maintenance of linguistic identities. The European Charter has become a catalyst promoting new language provision for Europe's linguistic communities in the name of a pluralist Europe. ${ }^{15}$ The next section considers how policy-makers have made identity recognition central to concepts of justice.

\section{Justice as identity}

The recognition of linguistic identity in international human rights documents has been propelled both by the influence of identity politics and contemporary international conflict management policies, which have rejected earlier assimilatory modernisation strategies. Assimilatory modernisation strategies posited economic development as key to promoting social justice and international peace. Within the modernisation model, an inverse link was made between linguistic diversity, and national and social development. ${ }^{16}$ Policy discussions considered whether linguistic homogeneity was a consequence of modernisation or a prerequisite. ${ }^{17}$ Hence linguistic diversity was not regarded as part of social justice under the modernisation model, but even counter to social justice as a possible obstacle to development.

However the negative policy view of linguistic diversity changed as modernisation strategies came under criticism for undermining the stability of societies and creating frustrated, alienated and rootless individuals. ${ }^{18}$ Modernisation's failures generated concern that international policy should tackle anomie and devise sustainable development policies which would foster stable functional communities. Official policy was reinforced by developments in radical politics away from Marxianinspired accounts which posited the proletariat as a progressive class ultimately seeking to extinguish itself as a class. The new identity-based politics that developed in the 1960s, disenchanted with both Western and Soviet modernisation models, instead sought empowerment of group identities as an approach to address discrimination and promote social justice. Against the previous assimilatory modernisation models, recognition of identity has become an important strategy to prevent the alienation of marginalised groups and secure their social inclusion. ${ }^{19}$ Low self-esteem and lack of identity recognition is regarded as being at the root of many social problems today. ${ }^{20}$ Consequently assimilationist policies are viewed negatively as violating people's identities rather than socially progressive.

These concerns over securing identity are evident in linguistic human rights advocacy, which views linguistic identity as crucial to securing individuals' identity and psychosocial well-being. Identification with a specific language is treated as essential 
to a community's identity and self-esteem, which in turn is seen as crucial to securing a community's well-being and fostering harmonious relations between communities and preventing violent conflict. Thus linguistic human rights have become part of international governance. Protecting linguistic identities as part of fostering selfesteem is given an important role to address the insecurities of people both domestically and globally. Linguistic human rights have, for example, been related by advocates 'to the solution of some of Africa's grave social, economic and political problems'. ${ }^{21}$ Since language is made core to identity, then a language's demise is seen as annihilating identity. In turn, the linguistic human rights literature conceptualises the death of languages as linguicide or linguistic genocide. The Genocide Convention's failure to recognise linguistic genocide is deplored. ${ }^{22}$ Necessary language rights in this model of justice therefore encompass specific language recognition. Accordingly, linguistic human rights are being advanced today as rights of difference against assimilation in which language loss is equated with social pathology. ${ }^{23}$

Since linguistic identification is seen as core to securing identity, there is more sympathy for recognising subjective linguistic identifications, that is, claims for language recognition based on a community declaring itself to be a distinct language community. Equally policies to protect the 'social conditions of production' of communities have been demanded to facilitate linguistic identity maintenance. ${ }^{24}$ Yet claim-making by marginalised groups through identity rights may simply represent attempts to gain the rights, freedoms and social goods enjoyed by other citizens, especially when groups astutely anticipate that contemporary policy responses favour identity claims rather than general claim-making. ${ }^{25}$ Furthermore a linguistic model treating language erosion as fostering social pathology supports linguistic identity rights becoming an obligation over individuals. Accordingly, some identity rights advocates are sympathetic to limiting freedom of choice to impede linguistic assimilation out of a linguistic minority. ${ }^{26}$

However, at times the promotion of linguistic identities to provide self-esteem seems to resemble an attempted bureaucratic quick-fix to the problem of securing identity and a substitute for social justice in circumstances of post-modern malaise. As an Australian civil servant admits, speaking on the lack of social prospects for poor Aboriginal youth, 'One of the things that will keep them going is to keep them strong in their own culture'. ${ }^{27}$ Moreover, critical voices are being raised over unintended negative consequences of identity recognition. ${ }^{28}$ Concern has been raised that identity-based claim-making risks solidifying differences between people instead of overcoming social inequalities. For justice based on special pleading risks fostering rival victim claim-making led by group representatives whose social position within and outside their community relies upon their community's marginalised condition. Consequently identity-based claim-making may encourage social problems being conceptualised as competing identities and exacerbate inter-ethnic tensions. Again identity rights may be invoked against communities ${ }^{29}$ or within communities reinforcing undemocratic power relations and group conformity. ${ }^{30}$ These criticisms are relevant to the experience of former Yugoslavia and the new states as I will highlight below.

\section{Discriminating language divisions}


Before I examine BCS language politics, I need first to return to the question of when is a language because this is fundamental to proper anti-discriminatory language planning and is at issue in the BCS language disputes. What is a language under international human rights instruments remains muddled despite its obvious importance. Human rights advocates, in their haste to establish a human rights framework, have overlooked the problem of determining when a language exists, and concentrated on codifying rights and monitoring procedures. The European Charter exceptionally provides a definition and explanatory notes. However its practice contradicts its own definition of a language which 'does not include dialects of the official language of the state'. ${ }^{31}$

What criteria can be used to determine when a distinct language as opposed to a dialect exists? Essentially the criteria fall into two sorts: comparative linguistic criteria or subjective criteria involving the speakers' identification of themselves as having a distinct linguistic identity. ${ }^{32}$ Differences between external and internal definitions of a language's existence commonly relate to the dialect/language distinction. Under external linguistic categorisation, American and British English are varieties of the same language, as are Dutch and Flemish, although they may have different titles. The explanatory report to the European Charter expressly states that the Charter does not recognise a language on the basis of personal claims:

The concept of language as used in the charter focuses primarily on the cultural function of language. That is why it is not defined subjectively in such a way as to consecrate an individual right, that is the right to speak "one's own language", it being left to each individual to define that language. ${ }^{33}$

The explanatory report further outlines that the Charter does not recognise a language on the basis of ethnic minority claims:

Nor is reliance placed on a politico-social or ethnic definition by describing a language as the vehicle of a particular social or ethnic group. Consequently, the charter is able to refrain from defining the concept of linguistic minorities, since its aim is not to stipulate the rights of ethnic and/or cultural minority groups, but to protect and promote regional or minority languages as such. ${ }^{34}$

Again the explanatory report reiterates how the Charter is not designed to protect regional dialects:

These languages must clearly differ from the other language or languages spoken by the remainder of the population of the state. The charter does not concern local variants or different dialects of one and the same language. ${ }^{35}$

Nevertheless, in recent years, both minority rights advocacy and sociolinguistics have become more sympathetic towards subjective identification, along with endorsing 'a maximalist position for minorities'. ${ }^{36}$ So subjective identifications have been given more weight, although linguist advocates would not necessarily support certain claims to language status which comparative linguistic criteria would challenge. Indeed, 
subjective language identifications have been recognised under human rights regimes, including the European Charter, despite its provisions to the contrary. For the European Charter allows subjective criteria to be used by the signatory state in determining whether a language exists. As the explanatory report goes on to outline, the Charter:

does not pronounce on the often disputed question of the point at which different forms of expression constitute separate languages. This question depends not only on strictly linguistic considerations, but also on psychosociological and political phenomena which may produce a different answer in each case. Accordingly, it will be left to the authorities concerned within each state, in accordance with its own democratic processes, to determine at what point a form of expression constitutes a separate language. ${ }^{37}$

Overlooked in this position outlined by the explanatory report is how policies maximising identity distinctions can demarcate exclusion rather than inclusion. Human rights advocates expect states to recognise minority rights and that minority language rights help minorities resist negative stereotyping and overcome discrimination and marginalisation. The identity politics informing human rights thinking leads declarations of distinct identities to be associated positively with social inclusion and pluralism. Human rights regimes are not, however, sensitive to how the very recognition of identity rights can be discriminatory and legitimise ethnic divisions.

\section{Discriminating BCS language politics}

I now turn to BCS language politics and how language as a symbol of identity rather than a means of communication has triumphed in official pronouncements on the language. ${ }^{38}$ In looking at BCS language politics, it is useful to compare the language question in relation to American and British English because it indicates for the nonspeaker problems with existing language recognition policies and the nature of linguistic discrimination experienced.

Subjective identification and its recognition are at the crux of the BCS language question, but to demonstrate this and before discussing the appropriateness of international responses, I need to highlight what comparative linguistic criteria lead most foreign linguistic experts to define a common language. ${ }^{39}$ As the Slavonic and East European Resource Center declares, it is the academic norm 'to treat BCS as one language', because although the 'language formerly known as Serbo-Croatian has split into three separate standard languages: Bosnian, Croatian, and Serbian (BCS) [...] all of these standards continue to be based on the same basic dialect type'. ${ }^{40}$

According to comparative linguistic analysis, the modern standard language in Bosnia, Croatia, Montenegro and Serbia remains the štokavian dialect ('sto' being the word for 'what' in the standard dialect). Within the štokavian dialect there are two key variants identified as the Western and the Eastern variants, or the ekavian or ijekavian variants, because their primary distinction is based on the divergent development of a Slavonic vowel: 'e' in the Eastern variant, and 'je' or 'ije' in the Western variant, for example, the word milk is 'mleko' and 'mlijeko' respectfully. ${ }^{41}$ 
The ekavian variant is the dominant variant of Serbia, while the ijekavian variant is spoken in Croatia as well as southern Serbia, Bosnia and Montenegro. There are also some other distinct features, notably lexical differences across the regions. Commonly cited lexical differences between the standard spoken in Croatia and Serbia include the word for bread (kruh/hleb), train (vlak/voz) or the months of the year, while the dialects spoken in Bosnia span these lexical differences in important respects, as well as more consciously retaining certain Turkish elements. A visible difference is in the use of the Latin and Cyrillic scripts, the latter was rarely used in Croatia, except in the Krajina region, while its use in Bosnia common before the war became confined to the Bosnian Serbs in the course of the war. Thus the old Bosnian textbooks would be printed in either script. A single textbook might contain both, the script alternating in the chapters. Likewise the Sarajevo-based Oslobodenje newspaper would alternate the script on its pages, whereas the Belgrade-based Politika used Cyrillic and the Zagrebbased Vjesnik used Latin. Students in Bosnia, Montenegro and Serbia would write in either script, though there was a growing personal preference for using the Latin script in their note-taking for the sake of speed, while students in Croatia would write in the Latin script. Moreover the use of two scripts was previously officially celebrated as symbolising the language's inclusiveness and the country's internationalism in its embrace of both an Eastern and Western cultural heritage. In contrast today the existence of two scripts is invoked to demonstrate inherent differences.

Such was the previous familiarity and inter-changeability of the Latin and Cyrillic scripts that students in Bosnia barely had a consciousness of whether a text was in Latin or Cyrillic in stark contrast to the political sensibilities today. I remember as an exchange student at Sarajevo University in the 1980s being given a collection of poetry in Cyrillic by a fellow student, a Bosnian Muslim from Srebrenica who did not register that the book was in Cyrillic until I mentioned the fact. Compare this lack of consciousness to how being taught Cyrillic is regarded today as oppressive by nonSerbs. Thus a recent brief report in the Bosnian Muslim teacher, quoted in a recent report in the Times Higher Education Supplement, a singles out inter alia how in a Serbian-dominated Srebrenica 'Muslim children have to read and write in Cyrillic', ${ }^{42}$ illustrating how Cyrillic is experienced as symbolic violence today, whereas the script did not necessarily register with Bosnian students in the past when the script was depoliticised.

The regional linguistic differences have been described as minimal and not impeding mutual comprehension and as being less significant than between American and British English. ${ }^{43}$ Consider distinct features of American and British English such as gotten/got, toward/towards as well as lexical variations such as pacifier/dummy, diaper/nappy or pitcher/jug. However, the regional variations in these four former Yugoslav republics assume huge political significance because of ethnic divisions, whereas the differences between American and British English are not politicised in the same manner. ${ }^{44}$

The sociolinguist James Tollefson has written how, 'language policy is embedded in the rise of the state'. ${ }^{45}$ This linkage between language and statehood is crucial to understanding BCS language politics. Linguistic differences loom large today because the assertion of separate languages helped support political claims to separate statehood based on the Romantic ideal of one nation, one language. 
Regional variations became sharply politicised the war with each ethnic group encouraged to take its linguistic cue from the capital city it was orientated towards: that is, the Croats from Zagreb, the Serbs from Belgrade and the Bosniacs (Muslims) from Sarajevo. The cleavages in linguistic identity are evident in Bosnia with instances of people from the same village speaking the same local dialect demanding their distinct language rights. ${ }^{46}$ The present language claims may be contrasted with earlier nationalist movements in the region seeking a unified state, which emphasised a common language despite greater regional variance in the past. Interestingly Croatian linguists of nineteenth century led codification of a shared standard language, while Croatian linguists of the present day led the idea of distinct languages towards legitimising claims to independent statehood. Thus along with the constitutional codification of Croatian as a distinct language and new grammars, dictionaries and textbooks, Croatian newspapers began to carry new language advise columns informing readers on how to speak a purer Croatian. In contrast, Serbian official policy, politically attached to a unified state, was slower to endorse a distinct Serbian language and less assiduous in pursuing language difference. Bosnian Serb language policy was more politicised than in Serbia itself, linked to efforts to legitimise Republika Srpska as well as strengthen its links to Serbia. In the course of the war, the ekavian variant became championed as the language of Bosnian Serbs and Cyrillic their script, although people in Bosnia speak the ijekavian variant and had used both scripts. Tellingly, while Bosnian Serb public figures vainly struggled to comply with the decree, documents produced in public institutions often continued to be typed in the Latin script, because they lacked the resources to replace the old Latin script typewriters. Conversely, for Bosnian Croats and Bosniacs, the previous common language policy requiring the learning of Cyrillic became popularly conceptualised as violating their human rights. Meanwhile, Bosnian advisers also began to codify a distinct Bosnian language.

Tollefson goes on to state how, 'commonality of language is one of the major sources for the feeling of security-through-belonging that ties individuals to nation-states'. ${ }^{47}$ Hence declarations of linguistic independence symbolically denying the commonality of language with the other two ethnic groups also contribute to removing their 'feeling of security-through-belonging'. Typical linguistic discrimination related to members of ethnic minorities finding their teaching posts challenged because they were deemed not to speak the official language, although other colleagues with the same local accent did not face these problems. Likewise typical linguistic discrimination related to documents such as birth, marriage or death certificates, property title deeds or professional certificates being challenged if written in the wrong script or wrong variation and having to pay for official translations for the documents to be formally recognised.

Shoring up declarations of linguistic independence, there has been readiness to declare the other ethnic groups as belonging to linguistic minorities. The continuing strong correspondence in the language spoken across the region, however, has made claims impossible to sustain on comparative linguistic criteria. Consequently subjective criteria have been embraced by those championing the idea of distinct Bosnian, Croatian, Montenegrin and Serbian languages. Claims to linguistic independence have stressed the paramountcy of subjective criteria in determining language status as well as script over the spoken word. ${ }^{48}$ The linguistic human rights model endorsing difference became complicit in linguistic discrimination, rather than 
straight-forwardly protecting ethnic minorities. For example, Croatia declared Croatian to be the official language of the state and Serbian as one of its minority languages under the European Charter, although the Charter expressly states that it does not recognise a dialect of the official language as minority language. ${ }^{49}$ The Charter's mechanisms assume that minority recognition is positive for minorities and therefore duly demand that Croatia comply with minority language provisions under the Charter. However the significance of designating linguistic minority status, of being excluded from the standard is to be symbolically excluded from mainstream society. ${ }^{50}$ In sum, language recognition in these circumstances denies correspondence, denies affinity, denies communication and denies 'the feeling of security-thoroughbelonging'. 51

The declarations of linguistic independence are explicable in the context of war and state-making and can expect to relax as the new states become assured in their statehood. Croatian newspapers, for example, no longer devote many column inches to advice on the Croatian language. However, international linguistic human rights as identity rights could reinforce ethnic linguistic divisions. Alternatively international regional linguistic experts such as the Slavonic and East European Language Resource Center have sought to separate again the language question from questions of statehood, declaring in the introduction to its website how, 'While recognizing the countries of Bosnia-Herzegovina, Croatia, and Serbia-Montenegro as separate, independent states, users of the current webliography are encouraged, as is the Academic norm, to treat BCS as one language .... 52

\section{Linguistic identity rights deterring coexistence}

If international linguists have been generally cautious about endorsing the idea of distinct Bosnian, Croatian, Montenegrin and Serbian languages, ${ }^{53}$ international negotiators and human rights advocates have been more willing to do so. International documents sometimes refer to distinct Bosnian, Croatian and Serbian languages or provide three distinct translations of a particular document, thereby legitimising the idea of mutual incomprehensibility. The 1995 Dayton Agreement, for example, was translated from English into three Bosnian, Croatian and Serbian versions, ${ }^{54}$ while the 1994 Washington Accords was translated into a Bosnian and Croatian version. Similarly the Constitution of the Federation of Bosnia and Herzegovina, set up by the 1994 Washington Accords stated, 'The official languages of the Federation shall be the Bosniac language and the Croatian language. The official script will be the Latin alphabet'. ${ }^{55}$ Subsequently the Federation's Constitution revised under international direction now states, 'The official languages of the Federation of Bosnia and Herzegovina shall be: Bosnian language, Croat language and Serb language. The official scripts shall be Latin and Cyrillic'. ${ }^{56}$ Likewise, the relevant provision of the Constitution of Republika Srpska revised under international direction now reads, 'The official languages of the Republika Srpska are: the language of the Serb people, the language of the Bosniak people and the language of the Croat people. The official scripts are Cyrillic and Latin'. ${ }^{57}$ Symbolically the website of the Office of the High Representative, designated to supervise Bosnia, refers to other languages, namely Bosnian, Croatian and Serbian with separate links. ${ }^{58}$ Similarly internationally-drafted election documentation in Bosnia is drawn up in three versions. Again Croatia's declaration of Serbian as one of its minority languages upon ratification of the European Charter in 1997 raised no international opposition. This stance is in line 
with the growing endorsement of self-definitions and the advocacy of maximalist positions for minorities. Instead international human rights experts criticised Croatia for failing to provide sufficient Serbian language provision for its ethnic Serbs, and also failing to recognise the Bosnian language as a minority language.

Equally consider briefly the language provision for refugees in host countries, which is all too often shambolic. Guidance notes have proliferated in this area. Take this statement from an Australian memo on Bosnian refugees' welfare. It advises:

It is offensive to Bosnians to be offered information in Serbian or Croatian with an assumption that those languages are similar and understandable to Bosnians. They often refuse to take it. ${ }^{59}$

Here distrust in an interpreter of another ethnicity is conflated with its expression as language difference. But it is one thing to identify that Bosnian Muslim refugees might understandably be distrustful of ethnically Croatian or Serbian interpreters because of the war and advise against their use on that ground alone and quite another to endorse the nationalist position on separate languages. Such misdiagnosis only mystifies inter-ethnic divisions.

International responses promoting special language rights and provision have misrepresented the interests of the ethnic groups speaking a shared language and have been detrimental overall to interethnic relations. Consider simply how while Croatia has been criticised by international experts over its provision for Serbian and Bosnian, international officials in Bosnia have been grappling with how linguistic identity rights may affirm divisions and marginalise minorities. Rather late in the day, international officials began tacitly to acknowledge how recognising subjectivelydefined linguistic identities could hinder inter-ethnic coexistence. International pragmatic support for three distinct Bosnian, Croatian and Serbian languages from what was previously treated as single language has hindered the reintegration of Bosnian education since the end of hostilities, as international reports have subsequently highlighted. ${ }^{60}$ The unintended but predictable consequences can be seen in the 1997 Bosnian decree for segregated education, defended by the Bosnian Minister of Education in terms of fulfilling minority rights requirements. International officials were horrified at the decree, but it reflected the logic of international linguistic human rights as identity rights. Ironically, Bosnian school textbooks revised under international supervision call the language 'nas jezik' ('our language') ${ }^{61}$, that is, they anonymise the language and draw back from language rights as identity claims in their efforts to overcome language discrimination and reintegrate schooling. Similarly the issue of language has proved a difficulty in integrating higher education in Bosnia. In the words, of Zdravko Grebo, a law professor at Sarajevo University, language dialects are used as an excuse for remaining separate'. ${ }^{62}$ A proposed Framework Law of Higher Education floundered in 2004 on the language question. Again interestingly Professor Grebo highlights how 'the fact that books for courses are usually bought in English, French or German makes a mockery of this', that is, the assertion of separate linguistic identities is absurd when universities increasingly rely on foreign textbooks anyway. Effectively proponents of reform, it seems, are trying to sidestep the language question by promoting the use of 'foreign lecturers and teaching in English'. ${ }^{63}$ Ironically then we have the proposed erosion of the use of the mother 
tongue and the use of a foreign language in Bosnian higher education, that is, a solution which goes counter to the philosophy of linguistic human rights advocates.

Finally by way of analogy, consider again the relationship between British English and American English. Would we consider British English and American English to be distinct languages? Should special language provision be provided for ethnic Britains in the United States? No doubt an individual would expect to be understood and documents in British English, such as birth or marriage certificates, to be accepted by US officials without being required to translate them into American English. However, do they require special linguistic rights such as separate public schooling in British English, the translation of official documents into British English, the right to a court interpreter to recognise the individual's British English linguistic identity? Yet international responses to language politics in the post-Yugoslav states have been ill-thought out and remain contradictory. International linguistic rights approaches have not properly considered how language rights as identity recognition might actually be detrimental to members of ethnic minorities and interethnic relations.

The linguistic human rights literature takes recognition of linguistic identity as a selfevident good and as a measure of the advancement of rights. However, the possibility that linguistic rights as identity rights may become complicit in ethnic discrimination and the denial of rights has not been addressed by the advocacy literature. Significantly BCS language politics and international responses illustrate how ratification of subjectively-defined linguistic minorities may endorse exclusionary politics and discriminate against ethnic minorities.

\footnotetext{
${ }^{1}$ Susan Mendus, 'Human Right in Political Theory.' Political Studies 43, 1995, p. 17.

${ }^{2}$ Arendt, Hannah (1958) The Origins of Totalitarianism. London: George Allen \& Unwin, p. 282.

${ }^{3}$ Constitution of Bosnia and Herzegovina, Article 2, in The General Framework Agreement, 1995, Annexe 4. http://www.ohr.int/dpa/default.asp?content_id=372

${ }^{4}$ Constitution of Bosnia and Herzegovina, Article 4(2), in The General Framework Agreement Annexe 4,: Annex 41995 http://www.ohr.int/dpa/default.asp?content_id=372

${ }^{5}$ R. E. Hamel, 'Introduction: linguistic human rights in a sociolinguistic perspective', International Journal of the Sociology of Language, Vol. 27 (1997), p. 119.

${ }^{6}$ Sandra Del Valle, Language Rights and the Law in the United States: Finding our Voices. Clevedon: Multilingual Matters, p. 2.

${ }^{7}$ R. E. Hamel, 'Introduction: linguistic human rights in a sociolinguistic perspective', International Journal of the Sociology of Language, Vol. 27 (1997), p. 123.

${ }^{8}$ R. Phillipson and T. Skutnabb-Kangas (eds), Linguistic Human Rights: Overcoming Linguisitic Discrimination (Berlin and New York: Mouton de Gruyter 1994).

${ }^{9}$ Sandra Del Valle, Language Rights and the Law in the United States: Finding our Voices. Clevedon: Multilingual Matters, p. 344.

${ }^{10}$ Article 27.

${ }^{11}$ Article 1, emphasis added.

12 Article 4, emphasis added.

${ }^{13}$ Article 14, emphasis added.

${ }^{14}$ European Charter for Regional or Minority Languages, Application of the Charter in Croatia. Report of the Committee of Experts on the Charter, Strasbourg, 20 September 2001, paragraph 62.

${ }_{15}$ Council of Europe, European Charter for Regional or Minority Languages, Explanatory Report, 1993, paragraph 32.

${ }^{16}$ Stanley Lieberson, Language Diversity and Language Contact. Stanford: Stanford University Press, p. 19.
} 
${ }^{17}$ Stanley Lieberson, Language Diversity and Language Contact. Stanford: Stanford University Press, p. 19.

18 Peter Berger, Brigitte Berger and Hansfried Kellner The Homeless Mind: Modernization and Consciousness. Harmondsworth: Penguin, 1974; E.F. Schumacher, Small is Beautiful: A Study of Economics as if People Mattered. London: Blond \& Briggs, 1973.

19 A. Honneth, The Struggle for Recognition: The Moral Grammar of Social Conflicts (Cambridge: Polity Press 1995), Charles Taylor, 'The Politics of Recognition', in Amy Gutman (ed.) Multiculturalism: Examining the Politics of Recognition. Princeton: Princeton University Press.

${ }^{20}$ Sandra Del Valle, Language Rights and the Law in the United States: Finding our Voices. Clevedon: Multilingual Matters, p. 82, note. 21.

${ }^{21}$ Phillipson and Skutnabb-Kangas, 1994, p. 345.

${ }^{22}$ Sandra Del Valle, Language Rights and the Law in the United States: Finding our Voices. Clevedon: Multilingual Matters, p. 341.

${ }^{23}$ R. E. Hamel, 'Language conflict and language shift: a sociolinguistic framework for linguistic human rights', International Journal of the Sociology of Language, Vol. 27 (1997); Skutnabb-Kangas and Phillipson, 1994.

${ }^{24}$ R. E. Hamel, 'Language conflict and language shift: a sociolinguistic framework for linguistic human rights', International Journal of the Sociology of Language, Vol. 27 (1997), p. 122, emphasis added.

${ }^{25}$ C. B. Paulston, 'Epilogue: some concluding thoughts on linguistic human rights', International Journal of the Sociology of Language, Vol. 27, (1997).

${ }^{26}$ J. Maurais, 'Regional majority languages, language planning, and linguistic rights', International Journal of the Sociology of Language, Vol. 27 (1997), pp. 135-160; Taylor (note 48).

${ }^{27}$ Quoted by Mark Abley, Spoken Here: Travels Among Threatened Languages. Boston and New York: Houghton Mifflin Co, 2003, p. 22.

${ }^{28}$ Brian Barry, Culture and Equality: An Egalitarian Critique of Multiculturalism. Cambridge, MA: Cambridge University Press, 2001; Wendy Brown, States of Injury: Power and Freedom in Late Modernity. Princeton: Princeton University Press, 1995; Todd Gitlin, The Twilight of Common Dreams: Why America is Wracked by Culture Wars. New York: Owl Books, 1995; Kenan Malik, The Meaning of Race. London: Macmillan, 1995; Slavoj Zizek, The Ticklish Subject: The Absent Centre of Political Ontology. London and New York: Verso, 1999.

${ }^{29}$ H. Brookes and S. B. Heath (1997) 'Book Review: Overcoming Linguistic Discrimination, edited by T. Stutnabb-Kangas and R. Phillipson', International Journal of the Sociology of Language, Vol. 27 (1997), p. 199.

${ }^{30}$ Nancy Fraser, 'Social Justice in the Age of Identity Politics: Redistribution, Recognition, and Participation', in Nancy Fraser and Axel Honneth, Redistribution or Recognition? A PoliticalPhilosophical Exchange. London and New York: Verso, p. 76.

${ }^{31}$ European Charter for Regional or Minority Languages (1992), Article 1.

${ }^{32}$ Skutnabb-Kangas and Bucak (note 51) p. 364.

${ }^{33}$ Council of Europe, European Charter for Regional or Minority Languages, Explanatory Report, 1993, paragraph 17.

${ }^{34}$ Council of Europe, European Charter for Regional or Minority Languages, Explanatory Report, 1993, paragraph 17.

${ }^{35}$ Council of Europe, European Charter for Regional or Minority Languages, Explanatory Report, 1993, paragraph 32.

${ }^{36}$ Skutnabb-Kangas and Phillipson, 'Linguistic human rights, past and present' (note 15) p. 103.

${ }^{37}$ Council of Europe, European Charter for Regional or Minority Languages, Explanatory Report, 1993, paragraph 32.

${ }^{38}$ For informative analysis of the course of BCS language politics, see, for example, the work of Ranko Bugarski or D. Skiljan.

${ }^{39}$ See, for example, R. Greenberg, 'The Politics of Dialects Among Serbs, Croats, and Muslims in the Former Yugoslavia', East European Politics and Society, Vol. 10 (1996), pp. 393-415; K. Naylor, 'The Sociolinguistic Situation in Yugoslavia with Special Emphasis on Serbo-Croatian', in R. Bugarski and C. Hawkesworth (eds) Language Planning in Yugoslavia (Columbus: Slavica 1992), pp. 80-92. See also the Slavic and East European Language Resource Center web site http://seelrc.org/webliography/bcs.ptml

${ }_{40}$ The Slavic and East European Language Resource Center web site http://seelrc.org/webliography/bcs.ptml 
${ }^{41}$ C. Hawkesworth's Colloquial Serbo-Croat (London and New York: Routledge \& Kegan Paul 1986). p. Xviii.

${ }^{42}$ Kevin Weaver, 'Srebrenica still haunts Muslims', Times Higher Education Supplement, 2 December 2005 , p. 12.

${ }^{43}$ T. F. Magner, Introduction to the Croatian and Serbian language (Philadelphia: Pennsylvania State University Press 1991), p. ix.

${ }^{44}$ R. Burchill, The English Language (Oxford: Oxford University Press 1985); B. Bryson, Made in America: an informal history of the English language in the United States (New York: W. Morrow 1994); T. Gustafason, Representative Words: Politics, Literature, and the American Language, 17761865 (Cambridge: Cambridge University Press 1992).

45 James Tollefson, 'Language Policy and Power.' The International Journal of Sociology of Language. 1993, p. 93.

${ }^{46}$ I. Ravlić, 'Federacija na ispitu.' [The Federation is tested] Nedjeljna, 22 September 1995, p. 36.

${ }^{47}$ James Tollefson, 'Language Policy and Power.' The International Journal of Sociology of Language. 1993, p. 93.

${ }^{48}$ R. Katičić, 'Croatian linguistic loyalty', International Journal of the Sociology of Language, Vol. 47 (2001), p. 26; I. Pranković, 'The Croatian standard language and the Serbian standard language', International Journal of the Sociology of Language, Vol. 47 (2001), pp. 35-36.

${ }^{49}$ Article 9.

${ }^{50}$ E. Haughen, 'Dialect, Language and Nation.', in J.B. Pride and J. Holmes (eds) Sociolinguistics: Selected Readings. Harmondsworth: Penguin, 1972, p. 100.

51 James Tollefson, 'Language Policy and Power.' The International Journal of Sociology of Language. 1993, p. 93.

52 The Slavic and East European Language Resource Center web site http://seelrc.org/webliography/bcs.ptml

53 D. Škijan, 'From Croato-Serbian to Croatian: Croatian Linguistic Identity.' Multilingua, Vol. 19, 2000 , p. 6.

${ }^{54}$ The General Framework Agreement, 1995 http://www.ohr.int/dpa/

${ }^{55}$ Constitution of the Federation of Bosnia and Herzegovina, Article 6(1), "Official Gazette" of the Federation of Bosnia and Herzegovina, 1/94, http://www.ohr.int/ohr-dept/legal/oth-legist/doc/fbihconstitution.doc

${ }^{56}$ Constitution of the Federation of Bosnia and Herzegovina, Article 6(1), "Official Gazette" of the Federation of Bosnia and Herzegovina, 1/94, 13/97, 16/02, 22/02, 52/02, 60/02, 18/03, 63/03, http://www.ohr.int/ohr-dept/legal/oth-legist/doc/fbih-constitution.doc

${ }^{57}$ Constitution of Republika Srpska, Article 7(1), "Official Gazette” of Republika Srpska, 6/92, 8/92, 15/92, 19/92, 21/92, 28/94, 8/96, 13/96, 15/96, 16/96 and 21/96. http://www.ohr.int/ohr-dept/legal/othlegist/doc/rs-constitution.doc

${ }^{58}$ http://www.ohr.int

59 Worthington Di Marzio, Bosnian Community Focus Group Details. Victoria, Australia. http://www.info.vic.gov.au/resources/CALD/cald_bycommunity/BOSNIAN.pdf

${ }^{60}$ V. Lenhart, A. Kesidou and S. Stockmann, The Curricula of the "National Subjects" in Bosnia and Herzegovina: A Report to UNESCO (Heidelberg August 1999); Human Rights Coordination Centre, Overview of Educational Problems in BiH and Guidelines for Intervention (Sarajevo: OHR 1999), p. 12; World Bank, Bosnia-Herzegovina, Education Development Project: Project ID: BAPE58512 (21 June 1999).

${ }^{61} \mathrm{~S}$. Gazibara, and Z. Zekić, Naš jezik za 5. razred osnovne škole. [Our language for the fifth year of primary school] (Sarajevo: Svjetlost 2002).

62 David Jobbins, 'Bosnian bow to pressure to reform', Times Higher Education Supplement, 2 December 2005, p. 12.

${ }^{63}$ Ibid. 